\title{
Skrifkritiese opstandingsperspektiewe - beoordeel vanuit die gereformeerde teologie
}

\author{
Authors: \\ Carel Coetzee ${ }^{1}$ \\ Stephan Smith ${ }^{1}$ \\ Affiliations: \\ ${ }^{1}$ Faculty of Theology, School \\ for Dogmatology, North-West \\ University, Potchefstroom \\ Campus, South Africa

\section{Correspondence to:} \\ Carel Coetzee \\ Email: \\ callie.coetzee@nwu.ac.za

\section{Postal address:} \\ PO Box 20655, Noordbrug \\ 2522, South Africa \\ Dates: \\ Received: 14 July 2015 \\ Accepted: 21 Sept. 2015 \\ Published: 14 Dec. 2015 \\ How to cite this article: \\ Coetzee, C. \& Smith, \\ S., 2015, 'Skrifkritiese \\ opstandingsperspektiewe - \\ beoordeel vanuit die \\ gereformeerde teologie', In \\ die Skriflig 49(1), Art. \#2011, \\ 11 pages. http://dx.doi. \\ org/10.4102/ids.v49i1.2011

\section{Copyright:} \\ (C) 2015. The Authors. \\ Licensee: AOSIS \\ OpenJournals. This work is \\ licensed under the Creative \\ Commons Attribution \\ License.
}

\section{Read online:}

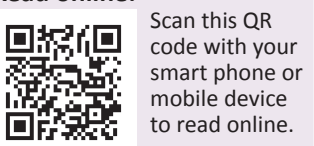

Hierdie artikel ondersoek die aard en omvang van skrifkritiese opstandingsperspektiewe binne die Suid-Afrikaanse teologie. Spesifieke klem word op die konsekwensies gelê wat skrifkritiese opstandingsperspektiewe vir die kernleerstukke van die Christelike geloof inhou. Verdere konsekwensies raak die hart van die individu se daaglikse geloofslewe en die praktyk van die kerk. Ten einde hierdie doel te bereik, word enkele skrifkritiese opstandingsperspektiewe kortliks gestel. Standpuntstelling word deur 'n beoordeling van elke standpunt vanuit 'n skrifverantwoorde teologie gevolg. Die standpunt word gestel dat skrifkritiese teoloë dikwels die ryke betekenis van Christus se opstanding ontken of onderbeklemtoon. Die navorsing vir hierdie artikel het verder getoon dat skrifkritiese opstandingsperspektiewe verreikende negatiewe konsekwensies vir 'n skrifverantwoorde teologie inhou. Die gevolgtrekking is dat skrifkritiese opstandingsperspektiewe onversoenbaar met die tradisioneel-reformatoriese leer van die Christologie is.

This article investigates the nature and extent of scripture-critical views of the resurrection in the context of South African theology. Special attention is given to the consequences that a scripture-critical view of the resurrection has on the core doctrines of reformed theology. Further consequences also affect the day-to-day faith of believers and the mission and effectiveness of the church. In order to conclude this investigation a number of scripturecritical views of the resurrection are critically investigated and evaluated from the perspective of the paradigm of reformed Dogmatics. Research has proven that scripture-critical scholars of theology displace or undervalue the impactful meaning of Christ's resurrection. Scripturecritical views of the resurrection have numerous negative consequences for the traditional doctrines of reformed theology. This article has determined that a scripture-critical view of the resurrection is not reconcilable with the traditional reformed doctrine of Christology.

\section{Inleidende opmerkings}

Dit is opvallend dat die kruisdood van Jesus in die meeste gevalle meer aandag as die opstanding geniet (König 2010:114). Dit beteken nie dat die een belangriker as die ander is nie, maar bloot dat die besondere betekenis van die opstanding in baie gevalle oorgesien of misken word.

Die vraag of Jesus werklik liggaamlik uit die dood opgestaan het, is fundamenteel vir die Christelike geloof (Van den Brink \& Van der Kooi 2012:397). ${ }^{1}$ Sonder die liggaamlike opstanding van Christus sou niks van Jesus se heilswerk enige betekenis vir die mens ingehou het nie. ${ }^{2}$ In aansluiting hierby word na Van den Brink en Van der Kooi (2012:395) verwys wat oortuig is dat die betekenis van Jesus se opstanding bevestigend is van wie Hy is en voorts ook van wat Hy vir ons as gelowiges beteken.

Tereg stel Du Rand (2004:44) dat die opstanding die skarnier is waarom die geloof draai. Dit draai na die verlede sodat die kruis daardeur betekenis kry. Dit draai na die hede sodat gelowiges reeds hier op aarde in 'n nuwe lewe kan leef. Dit draai ook na die toekoms sodat gelowiges kan weet dat die dood daardeur finaal oorwin is. Die feit bly staan dat die opstanding van Christus komplikasies vir die hele lewe inhou (Nederduitse Gereformeerde Kerk [NGK] 2013).

In die laaste dekades verskyn gereeld skrifkritiese artikels wat die liggaamlike opstanding van Christus bevraagteken of betwis (Viljoen 2002:2). Hierdie skrifkritiese opstandingsperspektiewe

1.Van den Brink en Van der Kooi (2012:396) stel die volgende: 'De opstanding of, breder, de verheerlijking van Jezus kunnen we beschouwen als de verbindende schakel tussen de vragen naar wie Hij is en wat Hij deed.'

2.Die Heidelbergse Kategismus (Sondag 17, vraag en antwoord 45; NHKA 1563) verklaar die drievoudige nut van die opstanding soos volg: Eerstens, het Hy deur sy opstanding die dood oorwin, sodat $\mathrm{Hy}$ ons die geregtigheid wat Hy deur sy dood verwerf het, deelagtig kon maak. Tweedens, word ons nou ook deur sy krag tot 'n nuwe lewe opgewek. Derdens, is die opstanding van Christus vir ons ' $n$ betroubare waarborg van ons salige opstanding. 
wat die kernaspekte van ons geloof bevraagteken, word in baie gevalle deur leiersfigure in die kerklike en die openbare lewe gemaak. Binne die grense van hierdie artikel word die skrifkritiese standpunte van Crossan (1994), Funk (1996), Müller (2006), Pienaar (2011), Spangenberg (2009) en Wedderburn (1999), kortliks gestel en vanuit 'n skrifverantwoorde teologie beoordeel.

In die lig van bogenoemde ondersoek hierdie artikel die volgende navorsingsvraag: Wat is die konsekwensies van skrifkritiese opstandingsperspektiewe vir die tradisioneelreformatoriese leer van die Christologie? 'n Verdere vraag word gevra, naamlik: Hoe kan 'n skrifverantwoorde teologie en die ware betekenis van Christus se opstanding gehandhaaf word, te midde van die toenemende groei van skrifkritiese opstandingsperspektiewe?

Ten einde hierdie vraag suksesvol te beantwoord, gaan 'n verskeidenheid skrifkritiese opstandingsperspektiewe ontleed en vanuit die paradigma van 'n skrifverantwoorde teologie beoordeel word. Navorsing geskied hoofsaaklik deur middel van 'n vergelykende literatuurstudie.

Die sentrale teoretiese argument van hierdie artikel word soos volg gestel: Skrifkritiese opstandingsperspektiewe is onversoenbaar met die tradisioneel-reformatoriese leer van die Christologie. Verder hou skrifkritiese opstandingsperspektiewe bepaalde negatiewe konsekwensies vir die daaglikse geloofslewe van individue in.

In teenstelling met Skrifkritici se vele alternatiewe verklarings vir Christus se liggaamlike opstanding, is dit die taak van gereformeerde teoloë om 'n skrifgefundeerde opstandingsperspektief te handhaaf (Van den Brink \& Van der Kooi 2012:37).

\section{Bepaalde vooronderstellings van die skrywers}

Volgens Jordaan (2005:8) bestaan daar geen neutrale grond nie. Dit is óf 'n kwessie van geloofsvooronderstelling óf van ongeloofsvooronderstelling. 'n Teoloog se Geloofsvooronderstelling is hiervolgens sy norm vir die verstaan van die Bybel.

Hierdie artikel word vanuit die paradigma van die reformatoriese teologie, meer spesifiek die Calvinistiese tradisie geskryf. Dit sluit onder andere die volgende vooronderstellings in:

- Dat die Skrif as die onfeilbare Woord van God gesien word en dat dit God se wil vir die mens volkome omvat (Nederlandse Geloofsbelydenis, Art. 7; Nederduitsch Hervormde Kerk van Afrika [NHKA] 1561). Die Woord van God is duidelik, genoegsaam, gesaghebbend en betroubaar veral sover dit die kernaspekte van die Christelike geloof betref (Heyns 1978:29). Alles wat God in sy Woord aan die mens openbaar, is die waarheid en is altyd geldend, selfs binne die konteks van 'n postmoderne era.
- Dat die gereformeerde belydenisskrifte in volle ooreenstemming met die Woord van God gehandhaaf word.

- Dat die kern van die Skrif en die evangelieboodskap in die persoon en werk van Jesus Christus gefundeer is.

- Dat hier meer spesifiek na die kruisinging en liggaamlike opstanding van Christus verwys word (König 2004:18). Christus is die volle openbaring van God en God kan alleen deur Jesus Christus geken word (Van de Beek 2002:178).

- Dat die vyf Solas van die Reformasie, naamlik Sola Gratia (slegs deur genade), Solus Christus (Christus alleen), Sola Scriptura (die Skrif alleen), Sola Fide (slegs deur die geloof) en Sola Deo Gloria (aan God alleen al die eer) nog steeds geldend is.

- Dat die ware interpretasie en verstaan van God se Woord alleen deur die verligtende werk van die Heilige Gees moontlik is.

\section{Wat is Skrifkritiek?}

Dit is belangrik om te verstaan wat met die term Skrifkritiek bedoel word. Ons leef in 'n samelewing waar mense lief is om ander te etiketteer of te kritiseer. Dieselfde geld ook vir die teologiese wetenskap. Daar moet dus versigtig te werk gegaan word om nie die bordjie van Skrifkritiek onnodig om teoloë se nek te hang nie. Dit is ook belangrik om te verstaan dat teoloë wat skrifkritiese standpunte handhaaf se bedoeling nie noodwendig is om die gesag van die Bybel te ondermyn nie. ${ }^{3}$ In baie gevalle probeer skrifkritiese teoloë, byvoorbeeld Bultmann (1984), met die beste bedoelings om die Woord van God vir die moderne mens toeganklik en verstaanbaar te maak.

Die definiëring van die term Skrifkritiek is baie moeilik aangesien dit nie in hedendaagse teologiese kringe so algemeen soos in die verlede gebruik word nie (Moulaison 2012:14). Die betekenis van terme soos tekskritiek en Skrifkritiek moet nie met mekaar verwar word nie. ${ }^{4}$

Die 1935-bundel, Koers in die krisis (De Wet 1935:92), dien as ' $n$ basis vir die verstaan van die term Skrifkritiek (Jordaan 2003:1). De Wet (1935:92) stel dat die mens sedert die opkoms van Modernisme op verskillende wyses aan die Bybel begin torring het. Hy definieer hierdie torringwerk as Skrifkritiek. Dit het volgens hom ten doel gehad het om die Bybel se absolute gesag oor die Christen se lewe en geloof te ondermyn. De Wet (1935:95) stel dit selfs sterker deur te verklaar dat Skrifkritiek as 'n eensydige aanval teen die moraal van die Bybel gesien kan word.

Dit kom kortliks daarop neer dat die basiese vertrekpunte van Skrifkritiek nie die Bybel as die geïnspireerde Woord van

3.Dit is belangrik om te verstaan dat ' $n$ skrifverantwoorde teologie ruimte vir die allegoriese interpretasie van sekere dele van die Skrif laat. Augustinus se opvattin allegoriese interpretasie van sekere dele van die Skrif laat. Augustinus se opvatting van die Nagmaalsleer kan as een so 'n voorbeeld uitgesonder word (Schulze 1988:151). Die allegoriese verstaan van die Skrif kan dus nie in alle gevalle aan
Skrifkritiek gelykgestel word nie. 4.Tekskritiek, in teenstelling met Skrifkritiek se bedoeling is dus primêr om vas te stel
watter teks die mees-betroubare een of die naaste aan die oorspronklike een is (Maré 1999:2). 
God aanvaar nie (Saaiman 2005:195) en ook die uniekheid en gesag van God se Woord ontken. Skrifkritiek gaan van 'n bepaalde waarde-oordeel uit wat behels dat die mens as regter oor die Skrif aangestel word en dat die Skrif ondergeskik aan die mens en sy oordele geplaas word (Jordaan 2005:1). In aansluiting by bogenoemde is Berkouwer (1967:426) van mening dat Skrifkritiek in terme van sy doel gedefinieer moet word, naamlik om die gesag van die Bybel te ondermyn.

Dit is dus niks vreemds dat Jordaan (2003:2) 'n noue ooreenkoms tussen Skrifkritiek en ongeloof bemerk nie. Hy (2003:2) gaan so ver om te stel dat Skrifkritiek sy oorsprong in ongeloof het. Skrifkritiek gee aan die interpreteerders van die Skrif vrye teuels om die betekenis van die teks te manipuleer om daardeur by hulle eie verstaansraamwerk in te pas.

In die praktyk kom Skrifkritiek daarop neer dat die mens nie meer deur die lewende Woord verander word nie, maar dat die Woord van God verander word om by die mens se eie vooropgestelde idees en agendas aan te pas. Berkouwer (1967:226) is verder van mening dat Skrifkritiek se lees en bestudering van die Bybel nie wetenskaplike neutraliteit of bevangenheid reflekteer nie. Hy (1967) stel:

Men wees erop, dat allerlei resultaten van het Schriftkritisch denken niet rusten op onbevangen luisteren naar wat de teksten der Heilige Schrift ons zeggen, maar op apriorische kaders, van waar ze werden gelezen en verklaard. (bl. 226)

Alhoewel dit baie moeilik is om die bestaan en oorsprong van Skrifkritiek te bepaal, meld Jordaan (2003:2) dat die vroegste voorlopers van Skrifkritiek alreeds in die Vroeë Kerk sigbaar was. Die oorsprong van Skrifkritiek kan dus na die kerkvaders van die vierde en vyfde eeu n.C. teruggevoer word toe die skole van Skrifverklaring na vore getree het.

In besonder kan hier na die religieuse filosowe van die Aleksandrynse skool van Skrifverklaring verwys word. Hulle het sterk klem op die allegoriese betekenis van die Skrif gelê en die letterlike verstaan van die Skrif as onvoldoende bestempel (Von Harnack 2011:147). Schulze (1988:43) stel in hierdie verband dat Origenes as die meester van die Aleksandrynse skool hom reeds vroeg met die beoefening van tekskritiek besig gehou het. Origenes het geglo dat die Griekse filosofie as 'n voorbereiding vir die Christendom gesien kan word. As gevolg van Origenes se Skrifbeskouing is hy op die Konsilie van Konstantinopel as ketter veroordeel. ${ }^{5}$

Alhoewel die vroeë voorlopers van Skrifkritiek nie so drasties was soos wat ons dit vandag ken nie, is die saadjie van ongeloof nogtans gesaai. Die allegoriese Skrifbenadering het regdeur die Middeleeue behoue gebly totdat Luther en Calvyn na die grammaties-historiese manier van eksegese teruggegryp het (Jordaan 2003:2). Die Aufklärung van die agtiende eeu het weer die menslike rede en historisiteit as 'n maatstaf vir die waarheid van die Skrif gebruik (Schulze 1988:6). Teen die einde van die agtiende eeu was daar

5.Origenes word ten spyte van sy bydra tot die ontwikkeling van Skrifkritiek steed as een van grootste kerkvaders van die Vroeë Kerk bestempel (Schulze 1988:43). reeds duidelike stromings van Skrifkritiek in die teologie teenwoordig.

Schulze (1988:244) stel dat die historiese denke tydens die Verligting tog 'n sekere mate van prioriteit aan die Christendom toegeken het, anders as die Historisme van die negentiende eeu wat die absoluutheid en prioriteit van die Christendom ontken het. Ten spyte van die vroeë stromings van Skrifkritiek het skrifkritiese standpunte in sy moderne vorm vir die eerste keer in die standpunte van die liberale teoloë van die negentiende en vroeë twintigste eeue skerp na vore gekom. Hierdie liberale teoloë het die weg vir die vloedgolf van skrifkritiese standpunte gebaan waarmee gelowiges vandag gekonfronteer word (Lane 2006:237-250). Die gevolge van Skrifkritiek is dat die mens aan homself oorgelaat is om die doel, rigting en betekenis in die lewe te vind.

Verder is dit duidelik dat Skrifkritiek die mens se gevoel as vertrekpunt gebruik om te bepaal watter dele van God se Woord as gesagvol aanvaar moet word (Saaiman 2005:199). In plaas daarvan dat die altyd geldende Woord van God as vertrekpunt geneem word, word die wisselende emosies van die mens nou die finale toetssteen (2005:197). Skrifkritiek in sy uiterste of postmodernistiese vorm (of dit nou intensioneel of onintensioneel is) word as 'n poging gesien om die fondamente van 'n skrifverantwoorde teologie te skud.

Terme wat oor die algemeen sinoniem met die term Skrifkritiek gebruik word, is relativisme of historiese kritiek. Skrifkritici is van mening dat dit wat in die Bybel geskryf staan bloot die mening of opinies van die verskillende samestellers van die onderskeie Bybelboeke weerspieël (Krüger 2006:29). ${ }^{6}$ Krüger (2006:29) meld verder dat die hartseer van so ' $n$ benadering is dat dit God vir die interpreteerder onkenbaar maak.

In teenstelling metSkrifkritiek benadruk Van den Brink en Van der Kooi (2012) die belangrikheid van 'n skrifverantwoorde interpretasie van God se woord:

Christelijk geloof wordt allereerst gevoed door de Bijbel. Net als andere christenen houdt de dogmaticus er dan ook een regelmatige omgang met de Bijbel op na. De dogmaticus weet echter ook dat de Bijbel op de een of andere manier normatief is voor wat christelijk geloof mag heten. (bl. 33)

Enkele van die belangrikste eksponente van Skrifkritiek word deur Lane (2006:233) uitgesonder as Schleiermacher (1768-1834), Albert Ritschl (1822-1889), Von Harnack (18511950), Bultmann (1884-1976) en Crossan (1934-vandag).

\section{Wat word onder skrifkritiese opstandingsperspektiewe verstaan?}

Met die term skrifkritiese opstandingsperspektiewe word die volgende bedoel: 'n Ontkenning of bevraagtekening van

6.'n Skrifbeskouing soos hierdie sou byvoorbeeld beteken dat dit wat Paulus in Romeine 1:26-27 geskryf het nie noodwendig meer vir vandag geldig is nie. 'n Tipiese skrifkritiese interpretasie sou van die veronderstelling uitgaan dat omstandighede intussen verander het en dat die moderne mens nou tot beter insigte gekom het (Krüger 2006:29). 
Christus se liggaamlike opstanding, of enige ander aspek wat met die opstanding verband hou, byvoorbeeld die leë graf of die na-opstandingsverskynings. Hierdie ontkenning of bevraagtekening van Christus se opstanding word aan Skrifkritiek toegeskryf aangesien die menslike rede, wetenskap of ander buite-bybelse historiese gegewens hoër as die gesag van God se Woord geag word.

Die Christologiese debat word tans onder andere gekenmerk deur teoloë wat op grond van 'n skrifkritiese hantering van die Skrif Christus se opstanding ontken of bevraagteken (Bosch 2009:x). 'n Oorsig oor die huidige Christologiese debat (spesifiek ten opsigte van Christus se opstanding) behels dat enkele van die eksponente en hulle standpunte kortliks hier aan die orde gestel word. Wat die eie konteks betref, word 'n belangrike vraag ook hier aan die orde gestel: Waar staan die Suid-Afrikaanse teologie te midde van die debat rakende Christus se liggaamlike opstanding? Ten einde hierdie vraag te beantwoord, word ' $n$ onderskeid tussen internasionale en Suid-Afrikaanse skrifkritiese eksponente getref.

Die doel van hierdie artikel is om 'n saaklike wetenskaplike beoordeling van bepaalde skrifkritiese standpunte te gee. Slegs teoloë wat werklik skrifkrities met die Woord omgaan en waarvan daar publikasies is wat daarvan getuig, word in hierdie artikel bespreek. 'n Verskeidenheid literatuur van kenners op hierdie gebied, internasionaal sowel as plaaslik, word ook aan die orde gestel, eerstens as kriterium om te bepaal watter teoloë as skrifkrities bestempel kan word en tweedens, vir die beoordeling van skrifkritiese opstandingsperspektiewe. Die volgende teoloë se literatuur word gebruik: Blanchard (2009), Boice (1986), Habermas en Licona (2004), Horton (2011), König (2009), Strobel (2009), Van de Beek (2002) en Van den Brink en Van der Kooi (2012).

Op internasionale vlak word die volgende teoloë uitgesonder as diegene wat skrifkritiese opstandingsperspektiewe huldig en hulle word almal ondersoek: Crossan en Wright (2006), bekend vir sy dialoog met Wright in The resurrection of Christ; Funk (1996), 'n aktiewe lid van die Jesus Seminaar met Honest to Jesus: Jesus for a new millennium; Spong (2001) met sy boek, Resurrection - Myth or reality; Lüdeman (1995) met sy boek, The resurrection of Jesus, history, experience, theology; en Wedderburn (1999) met Beyond resurrection.

BinnedieSuid-Afrikaanse konteks huldig Müller (2006) metsy boek, Opstanding, ${ }^{7}$ ook skrifkritiese opstandingsperspektiewe. Wanneer dit by skrifkritiese standpunte kom, kom die naam van Sakkie Spangenberg telkens na vore. Spangenberg is ' $n$ aktiewe lid van die Nuwe Hervormingsnetwerk wat daarop aanspraak maak dat hulle 'n sogenaamde 'alternatiewe tuiste' vir gereformeerde gelowiges bied wat ontuis in die tradisionele gemeentes geraak het. In Spangenberg (2009) se publikasie, Jesus van Nasaret, plaas hy 'n vraagteken agter Jesus Christus se heilswerk as die kern van die Christelike

7.Die feit dat Müller onder hierdie afdeling van die studie ressorteer, hang ten nouste saam met ' $n$ radio-onderhoud op RSG (2005) waar hy nie eenvoudig ja op die vraag kon antwoord of Jesus wel liggaamlik uit die dood opgestaan het nie. geloof. ${ }^{8}$ Van Aarde (2001), nog 'n Suid-Afrikaanse teoloog met sy boek, Fatherless in Galilee, is van mening dat Josef 'n fiktiewe skepping van die vroeë Christene was, omdat hulle die skande van Maria se buite-egtelike swangerskap daardeur wou wegsteek (2001:73). Onder Suid-Afrikaanse teoloë wat skrifkrities met die opstandingsleer omgaan, kan ook die volgende teoloë uitgesonder word: Moolman (2011), Naudé (2011), Pienaar (2011), Veldsman (1993) en Wolmarans (2010). Baie van bogenoemde teoloë se literatuur is vrylik op die webwerf van die Nuwe Hervormingsnetwerk of die Sentrum vir Eietydse Spiritualiteit beskikbaar. ${ }^{9}$

'n Goeie begrip van die term Skrifkritiek soos dit onder skrifkritiese opstandingsperspektiewe verstaan word, is belangrik alvorens na die volgende afdeling van die artikel oorgegaan kan word. Volgende aan die orde is 'n saaklike uiteensetting van die mees algemene skrifkritiese opstandingsperspektiewe en 'n skrifverantwoorde evaluering daarvan.

\section{Skrifkritiese opstanding- sperspektiewe en evaluering}

In hierdie afdeling word 'n verskeidenheid skrifkritiese opstandingsperspektiewe kortliks gestel en vanuit 'n skrifverantwoorde teologie beoordeel.

\section{Die evangelies bevat teenstrydighede wat die opstanding van Christus weerspreek ${ }^{10}$}

Verskeie skrifkritiese teoloë ontken Jesus se liggaamlike opstanding omdat hulle glo dat die opstandingsverhale in die Evangelies mekaar weerspreek.

Ter stawing van hierdie argument verwys Skrifkritici na geringe verskille in die Evangelieverhale, byvoorbeeld die aantal vroue wat die graf besoek het. Johannes verwys na een vrou (Joh 20:1), Mattheus na twee vroue (Matt 28:1) en Markus na drie vroue (Mark 6:1).

Op grond van enkele verskille met betrekking tot die omstandigheidsgebeure soos dit hierbo genoem is, is Skrifkritici van mening dat niemand regtig weet wat gebeur het nie. Die feit dat selfs die oorgetuies se weergawes van mekaar verskil, is vir Skrifkritici rede om te glo dat die Evangelies bloot die idees en gedagtes van die skrywers reflekteer en dus onbetroubaar is. ${ }^{11}$ Op grond van bogenoemde plaas Skrifkritici 'n vraagteken agter die historisiteit van die opstanding (Spangenberg 2004a:2).

Wat 'n beoordeling vanuit 'n skrifverantwoorde perspektief betref, is Habermas en Licona (2004:122) van mening dat die

8.Vir meer inligting oor Spangenberg en die Nuwe Hervormingsnetwerk kan die literatuur van Smith (2011) geraadpleeg word.

9.Die internetadresse hiervoor is www.nuwe-hervorming.co.za en www.spiritualiteit. co.za

10.Die bespreking is na aanleiding van die volgende teoloë: Carte Blanche (2002), Copan (1998), Moolman (2011:4), Naudé (2011:1) en Spong (2003:2).

11.Sien ook Von Harnack (2011:16) in hierdie verband. 
oënskynlike teenstrydighede in die Evangelies wat met die opstandingsgebeure verband hou, geensins op die historiese betroubaarheid van die opstanding betrekking het nie. ${ }^{12}$ Bosch (2009:331) voer aan dat die Evangelies 'n besondere eenstemmigheid toon betreffende die sentrale boodskap. ${ }^{13}$ Oënskynlike teenstrydighede in 'n getuienis is nie vir historici genoeg rede om te verklaar dat die insident nooit plaasgevind het nie (Boice 1986:350). Indien ooggetuies van 'n motorongeluk verskil oor watter motor eerste die kruising binnegegaan het, beïnvloed dit nie die feit dat'n ongeluk wel plaasgevind het nie.

Verskille in getuienisse dui juis daarop dat die verhaal uit onafhanklike weergawes bestaan van wat regtig gebeur het. Dit is verder ook so dat verskille in getuienisse verskillende aspekte van 'n saak verteenwoordig. Skrywers se agtergrond, kultuur, belange en temperament bepaal grotendeels watter aspekte van 'n saak onthou word (Wheaton 1973:529). Craig (1984) stel die volgende:

The differences that do exist are quite minor and are the result of unintentional mistakes. The text of the New Testament is every bit as good as the text of the classical works of antiquity. (p. 352)

\section{Die opstanding van Christus is ' $n$ mite en moet metafories verstaan word $^{14}$}

Habermas en Licona (2004:84) verdeel Skrifkritici se standpunte dat die opstanding metafories verstaan moet word in die volgende drie kategorieë:

- Die stories aangaande Christus se opstanding het met verloop van tyd gegroei. Hierdie standpunt behels dat die dissipels nooit bedoel het, of aanspraak daarop gemaak het dat Jesus liggaamlik uit die dood opgestaan het nie.

- Nie-historiese genreteorieë behels dat die stories rakende Jesus se opstanding nooit bedoel was om historiese waarheid te kommunikeer nie. Volgens hierdie teorie wou die dissipels bloot aan Jesus eer betoon deur bonatuurlike eienskappe aan Hom toe te skryf (Mcdowell 2009:117).

- Die opstandingsverhaal van Christus is op 'n variasie van mites van ander gelowe gebaseer (Habermas \& Licona 2004:84).

Skrifkritici verwys dikwels na gode soos Osiris, Tammuz, Adonis en Marduk as voorbeelde van gode wat gesterf en weer na die lewe teruggekeer het. Hulle is van mening dat Jesus se opstandingsverhaal geensins meer geloofwaardig as hierdie gode se verhale is nie.

In die beoordeling van bogenoemde standpunte kan gestel word dat die opstandingsverhaal nie die resultaat van 'n latere toevoeging kan wees nie, aangesien dit tot by die oorspronklike getuienisse teruggespoor kan word. Habermas

\footnotetext{
12.Sien ook Wheaton (1973:529) se argument betreffende die oënskynlike teenstrydighede in die Evangelies.

13.Vir meer verklarings aangaande die oënskynlike weersprekings rondom die opstandingsverhaal kan die werk van Geisler en Howe (1992) geraadpleeg word.

14. Hierdie bespreking is na aanleiding van uitsprake van onder andere Bultmann (1984:36), Copan (1998), Human (2004:235), Pienaar (2011:4) en Wolmaran (2002:64)
}

en Licona (2004:86) poneer dat die aanvanklike getuienis van die dissipels geensins ruimte gelaat het vir die teorie dat Jesus se opstandingsverhaal met die verloop van tyd gegroei het nie.

Indien Jesus se opstanding nooit bedoel was om letterlik verstaan te word nie, is daar steeds geen verklaring vir die leë graf nie en sou dit behels dat daar 'n verdere teorie moet wees om die leë graf te verklaar. In teenstelling met hierdie argument dui die literatuur van die Nuwe Testament (bv. Hand 2:29-31) daarop dat die opstanding van Jesus letterlik verstaan moet word. Habermas en Licona (2004:89) stel verder dat indien dit so maklik was om Jesus se opstanding as nie-histories af te maak, sou Skrifkritici van die vroeë era nie met allerhande alternatiewe verklarings vorendag gekom het nie. In teenstelling met Christus se opstandingsverhaal is die opstandingsverhale van ander gelowe vaag en onduidelik (Blanchard 2009:3-5). Christus se liggaamlike opstanding kan dus nie op dieselfde lyn as ander opstandingsverhale geplaas word nie (Craig 2009:395).

In die konteks van hierdie artikel val die klem op die liggaamlike opstanding van Christus. Die ruimte van hierdie artikel laat dit egter nie toe om in diepte tussen die lyn van kontinuïteit en diskontinuïteit met betrekking tot Christus se opstanding te onderskei nie. Christus se verheerlikte liggaam word deur verskeie aspekte gekenmerk wat die menslike verstand nie kan verstaan nie, byvoorbeeld die feit dat Maria Jesus nie in sy verheerlikte liggaam herken het nie (Joh 20:15-16), asook die feit dat Jesus se verheerlikte liggaam die vermoë gehad het om deur geslote deure te beweeg (Joh 20:19). Albei hierdie voorbeelde konstateer die lyn van diskontinuïteit wat die opstanding van Christus betref.

\section{Jesus se liggaam is gestee ${ }^{15}$}

Vanuit skrifkritiese perspektief behels hierdie siening dat Jesus se liggaamlike opstanding op 'n kombinasie van bedrogteorieë gebaseer word. Dit behels onder andere dat Jesus se liggaam óf deur die dissipels, óf deur ander mense gesteel is. Kortweg kom hierdie siening daarop neer dat die dissipels of andere doelbewus probeer het om mense te mislei deur voor te gee dat Jesus wel opgestaan het (Blanchard 2009:12). Die motief wat Skrifkritici vir hierdie diefstal voorhou, is dat die dissipels hulself die verleentheid wou spaar dat hulle moontlik verkeerd was oor Jesus.

Hulle het hiervolgens besluit om die liggaam te steel sodat dit die indruk sou skep dat Jesus wel opgestaan het. Dit is belangrik om hier melding te maak van Veldsman (1993:995) se 'eksperimentele argument', naamlik dat dat Jesus se liggaam die Vrydagnag gesteel is en toe herbegrawe is. Die feit dat Veldsman met hierdie gedagte eksperimenteer, plaas ' $n$ vraagteken agter sy hantering van die tradisioneelreformatoriese leer van Christus se liggaamlike opstanding. König (2009:259) is van mening dat Veldsman (1993:995)

15. Hierdie siening word bespreek na aanleiding van perspektiewe volgens Carte Blanche (2002), Copan (1998), Veldsman (1993:995) en Wedderburn (1999:64). 
se argument geensins die indruk skep dat dit bloot net 'n eksperiment was nie.

In die beoordeling van bogenoemde siening kan onder andere die volgende gestel word: Die drastiese verandering wat by die dissipels ingetree het kort na Jesus se kruisdood dui daarop dat hulle nie Jesus se liggaam gesteel het nie (Blanchard 2009:14). Habermas en Licona (2004:95) sê: 'Their willingness to suffer continuously and die for the sake of the gospel points to their sincerity, and points out a fatal flaw in the fraud theory.'

Verder verklaar dit geensins die na-opstandingsverskynings en die verandering in diegene wat Hom ontmoet het nie. Paley (1854:173) is van mening dat die mees oortuigende getuienis van die opstanding nie die leë graf was nie, maar juis die na-opstandingsverskynings. ${ }^{16}$

\section{Die dissipels en die vroue het die verkeerde graf besoek $^{17}$}

Volgens hierdie teorie van sommige skrifkritiese teoloë het die dissipels en die vroue vergeet waar Jesus begrawe was en het hulle die verkeerde graf besoek. Die leë graf wat hulle gevind het, was volgens hierdie argument nie regtig Jesus se graf nie, maar 'n ander graf. Hulle het hiervolgens verkeerdelik die afleiding gemaak dat Jesus uit die dood opgestaan het (Habermas \& Licona 2004:97).

Die gereformeerde teoloog Mcdowell (2009:190) is van mening dat hierdie argument eintlik niksseggend is. Selfs al sou die dissipels die verkeerde graf besoek het, verklaar dit nog nie Jesus se na-opstandingsverskynings nie. Die leë graf het nie een van die dissipels behalwe Johannes van die opstanding oortuig nie (Paley 1854:173). ${ }^{18}$

Paulus het tot bekering gekom op grond van 'n ontmoeting met Christus op die pad van Damaskus en nie op grond van die leë graf se getuienis nie (Hand 9:3). Verder bestaan daar ook geen historiese bewyse om die verkeerde-grafteorie te rugsteun nie (Mcdowell 2009:186).

\section{Jesus het nooit regtig aan die kruis gesterf nie ${ }^{19}$}

Die standpunt dat Jesus nooit regtig aan die kruis gesterf het nie staan ook as die 'Swoon theory' bekend. Mcdowell (2009:192) is van mening dat hierdie argument vandag nog net so aktueel is soos jare gelede. Volgens hierdie teorie het Jesus nooit werklik aan die kruis gesterf nie, maar hy het bloot sy bewussyn verloor as gevolg van die intense pyn en uitputting. Hierdie siening behels dat die Romeinse soldate van daardie era verkeerdelik bevestig het dat Jesus wel dood was. Skrifkritici voer dikwels die rede aan dat medici in

16. Blanchard (2009:19) stel die volgende: 'Those first Christians were utterly sceptical until they faced a fact that could not be denied.

17.Copan (1998) se siening dat Jesus se liggaam nooit regtig begrawe was nie, maar in ' $n$ vlak graf gegooi was waar wilde honde dit opgeëet het, kom prinsipieel op dieselfde argument neer.

18.Sien ook Driscoll en Breshears (2010:97) in hierdie verband.

19. Hierdie teorie is volgens Strauss (1879:392). daardie dae nog nie so gevorderd was soos wat dit vandag is nie. Hierdie teorie impliseer dat Jesus nooit liggaamlik uit die dood opgestaan het nie, maar bloot bygekom het nadat hy sy bewussyn herwin het (Mcdowell 2009:192).

In 'n beoordeling van die sogenaamde 'Swoon theory' is die volgende ter sake. Alhoewel daar vele geldige teenargumente vir hierdie teorie bestaan, is die algemeenste seker die feit dat daar bloed en water by die spieswond in Jesus se sy uitgekom het - 'n mediese bewys dat Jesus wel dood was. Verder was die Romeinse soldate wat die kruisiging toegedien het uiters bevoeg in hulle taak. Daar is geen manier wat hulle 'n fout sou begaan het om Jesus verkeerdelik dood te verklaar nie (Strobel 2009:28). Die soldate was so oortuig dat Jesus wel dood was, dat hulle nie sy bene gebreek het soos hulle dikwels met ander kruiselinge gedoen het nie (Joh 19:32, 33). Een van die grootste probleme met hierdie teorie is dat Skrifkritici dikwels die erns en graad van die wonde wat tot Jesus se dood aanleiding gegee het, onderskat (Van der Walt 2006:288)

Selfs volgens die tradisionele Romeinse kruisiging (wat vandag beter verstaan word as jare gelede) is dit 'n uitgemaakte saak dat die gekruisigde sou sterf (Mcdowell 2009:193).

\section{Psigologiese verskynsels verklaar Jesus se opstanding}

Onder die term psigologiese verskynsels word daar 'n geringe onderskeid getref tussen hallusinasies, sinsbedrog en visioene.

Habermas en Licona (2004:105) definieer 'n hallusinasie as 'n valse persepsie of gewaarwording van iets wat nie regtig bestaan nie. Skrifkritici soos Lüdeman (2012:4) gebruik verskeie redes soos hartseer en skuldgevoel as die oorsaak van die hallusinasieteorieë. Sinsbedrog hierteenoor kan gedefinieer word as 'n valse geloofsoortuiging terwyl die feite die teendeel bewys. Jim Jones en David Koresh van The People's Temple-gemeente is voorbeelde van charismatiese leiers wat daarin geslaag het om ' $n$ hele groep mense te mislei (Habermas \& Licona 2004:105). Hullehet hulle hele gemeente oortuig om selfmoord te pleeg omdat hulle geglo het dat God hulle na 'n beter plek wou neem.

Volgens hierdie beginsel word Jesus se opstandingverhaal aan die werk van charismatiese leiers in die Vroeë Kerk, byvoorbeeld Petrus toegeskryf. Skrifkritici verwys dikwels daarna dat die dissipels visioene gesien het eerder as hallusinasies. Dit is belangrik om te onderskei tussen subjektiewe visioene en objektiewe visioene.

'n Objektiewe visioen word gesien sonder dat die mens se sintuie gebruik is, alhoewel dit as 'n werklikheid ervaar word. Subjektiewe visioene hierteenoor is die produk van die mens se gedagtes en dit bestaan glad nie buite die denke van die betrokke persoon nie (Mcdowell 2009:229). Hiervolgens kan objektiewe visioene in uiterste gevalle 'n liggaamlike 
opstanding ontken, maar nie die feit dat daar een of ander vorm van opstanding plaasgevind het nie. Subjektiewe visioene hierteenoor bevraagteken die bestaan van die opstanding of na-opstandingsverskynings (Habermas \& Licona 2004:112).

'n Skrifverantwoorde beoordeling van bogenoemde standpunte, behels onder andere dat dit onmoontlik is dat almal wat Jesus na sy dood gesien het eenderse hallusinasies kon gehad het, aangesien hallusinasies nie kollektiewe insidente is waar almal dieselfde ervaring deel nie (Mcdowell 2009:230). Sinsbedrog kan nie Jesus se opstanding verklaar nie, want Paulus was nie deel van 'n charismatiese groep leiers soos die dissipels wat doelbewus mense kon beïnvloed het nie.

Paulus het buite die Christelike geloof gestaan en Jesus se fisiese verskyning aan hom het daartoe aanleiding gegee dat hy tot bekering gekom het (Habermas \& Licona 2004:109). Verder is Paulus se briewe die vroegste literatuur wat van na-opstandingsverskynings getuig (selfs vroeër as die Evangelies). Daar is ook geen aanduiding dat Paulus 'n visioen gesien het eerder as om ' $n$ ontmoeting met 'n liggaamlike Jesus te hê nie (Geisler \& Howe 1992:336). Dieselfde geld ook ten opsigte van Jakobus. Selfs al was visioene vir Jesus se verskynings verantwoordelik, verklaar dit nog nie die feit dat daar nie 'n fisieke liggaam in die graf was nie (Mcdowell 2009:229).

\section{Naturalisme ${ }^{20}$}

Omdat Christus se liggaamlike opstanding die wette van die natuur oorskry en beskou word as ' $n$ wonderwerk, glo naturaliste dat dit nie moontlik was nie. ${ }^{21}$ In teenstelling hiermee verwys Van den Brink en Van der Kooi (2012:33-34) na die taak van die dogmatiek om die veelvormigheid en teensprake van Bybelwetenskaplikes te verantwoord.

Naturaliste se benadering is eenvoudig - indien iets nie wetenskaplik moontlik is nie, het dit nooit plaasgevind nie (Habermas \& Licona 2004:132). Volgens naturaliste moet elke gebeurtenis in die verlede, teenwoordige of toekomstige tyd 'n natuurlike verklaring hê (Paley 1854:193). Enkele argumente van naturaliste ${ }^{22}$ word vervolgens gestel:

- Slegs dit wat wetenskaplik bewys kan word, is waar (Lennox 2011:58).

- Wetenskap het bewys dat nadat mense gesterf het, hulle nie weer lewendig kan word nie.

- Wetenskap het 'n antwoord vir alles, die mens het God nie nodig nie.

- Indien God wel bestaan, kan Hy nie inmeng in die natuurwette nie.

20. Hierdie sienswyse is volgens Bultmann (1984:4), Carte Blanche (2002), Müller (2006:9), Pienaar (2011:4) en Wedderburn (1999:77).

21.Sien ook Lennox (2011:19) se standpunte omtrent 'God of the gaps'.

22.Skrifkritiese teoloë wat op grond van naturalistiese standpunte Jesus se liggaamlike opstanding ontken, is Lüdeman (1995), Müller (2006), Pienaar (2011), Spangenberg (2004b), Spong (2003) en Wedderburn (1999).
- Wetenskap moet 'n natuurlike verklaring vir alles kan gee.

- Selfs al sou al die feite op 'n wonderwerk dui, sal daar nooit bo alle twyfel bewys kan word of dit wel 'n wonderwerk was nie.

- Wonderwerke van ander gelowe beïnvloed die geloofwaardigheid van wonderwerke in die Christelike geloof.

- Die waarskynlikheid in enige saak sal nooit op 'n wonderwerk dui nie.

Die feit dat naturalisme normaalweg nie bereid is om na die feite van die opstanding te kyk nie, aangesien dit nie binne hulle verstaansraamwerk inpas nie, is opmerklik (Mcdowell 2009:112). Binne die konteks van hierdie artikel kan naturalisme as enige siening of standpunt gesien word wat Christus se liggaamlike opstanding op grond van 'n tekort aan wetenskaplike bewyse ontken of bevraagteken.

Vanuit 'n skrifgebonde (reformatoriese) perspektief, kan die volgende beredeneer word. Sommige wetenskaplikes weier om enige historiese gegewens van Jesus se opstanding te bestudeer, aangesien hulle nie die wonderbaarlike wyse waarop God werk kan meet of verstaan nie (Mcdowell 2009:117). Wetenskaplikes redeneer dikwels dat iemand nie nadat hy gesterf het op 'n natuurlike manier weer lewend kan word nie. In Jesus se geval het hy nie op 'n natuurlike manier lewend geword nie, maar deur 'n wonderwerk van God. Verder is dit onwetenskaplik vir wetenskaplikes om hulself uit te spreek oor wat God kan doen en nie kan doen nie, aangesien hulle God nie ken nie.

Jesus se opstanding moet binne die breër raamwerk van sy lewe op aarde verstaan word (Geisler \& Howe 1992:333). Daar is verskeie ander gebeurtenisse wat op 'n bonatuurlike goddelike ingryping aanspraak maak, byvoorbeeld Jesus se maagdelike geboorte (Luk 1:27) en Jesus se wonderwerke op aarde (Joh 4:46).

\section{Jesus se opstanding was nie liggaamlik nie, maar geestelik ${ }^{23}$}

Volgens hierdie standpunt het Jesus nooit liggaamlik aan die dissipels en andere verskyn nie, maar wel in die vorm van 'n geestelike liggaam. Müller (2006:97) is byvoorbeeld van mening dat teoloë Jesus se opstanding 'n onreg aandoen deur dit tot 'n liggaamlike opstanding in te perk. Skrifkritici soos Funk (1996:259-260) verwys dikwels na verskeie tekste in die Nuwe Testament, byvoorbeeld Johannes 21:12 (die dissipels het Jesus nie herken nie) en 1 Petrus 3:18 (Jesus is gedood in die vlees, maar lewend in die gees) ter stawing van hulle argument. Dit beteken volgens Skrifkritici ${ }^{24}$ dat Jesus se opstanding uit die dood nie ' $n$ fisieke liggaamlike opstanding was nie, maar eerder 'n geestelike opstanding.

23. Hierdie siening is volgens Human (2004:232), Müller (2006:97), Pienaar (2011:8) en Wedderburn (1999:71)

24.Pienaar (2011), Spong (2001) en Wedderburn (1999) huldig byvoorbeeld hierdie standpunt. 
Die betekenis van die opstanding word nie aan die liggaamlike opstanding van alle vlees aan die einde van die tyd gekoppel nie, maar aan die feit dat Jesus reeds hier en nou in die harte van sy volgelinge moet opstaan (Spangenberg 2004b:6).

Vanuit 'n skrifverantwoorde perspektief kan hierdie standpunt soos volg beantwoord word: Paulus en Petrus se getuienis omtrent Jesus spreek nie van 'n geestelike ontmoeting nie, maar van 'n fisieke ontmoeting (vlg. onder andere Hand 1:1-11; Kor 15:44; Fil 3:21). ${ }^{25}$ Verder beeld die evangelies Jesus se opstanding as 'n fisieke opstanding uit (Craig 1984:380-384). Maria kon Jesus fisiek aanraak (Joh 20:1726); Jesus het saam met sy dissipels geëet (Luk 24:42); Jesus het vir Tomas uitgenooi om aan sy wonde te raak (Joh 20:27); en Jesus het verder ook saam met sy dissipels op die strand gestap (Joh 21:4).

Van den Brink en Van der Kooi (2012:402-403) stel in hierdie verband:

Her getuigenis van het lege graf in de Evangelien (Marc. 16:6 pp) onderstreept Gods concrete handelen aan dode Jezus. 'Hij is niet hier' - daarmee wordt de opstanding als lichamelijke gebeurtenis belklemtoond.

\section{Gevolgtrekking}

Nadat Strobel (2009), 'n voormalige ateïs, 'n deeglike studie van die opstanding van Christus gedoen het juis met die doel om dit ongeldig te verklaar, het hy tot die volgende gevolgtrekking gekom:

I filled page after page after page after page - until I finally realized that in light of the avalanche of evidence that points so powerfully toward the truth of Christianity, it would have required more faith to maintain my atheism than to become a Christian. (p. 55)

Navorsing het getoon dat geeneen van bogenoemde skrifkritiese standpunte daarin geslaag het om 'n geloofwaardige alternatiewe verklaring vir Jesus se opstanding en sy na-opstandingsverskynings te bied nie (Craig 1984:377). ${ }^{27}$

AlhoewelSkrifkritici se pogings om 'n alternatiewe verklaring vir Jesus se opstanding te bied nie oortuig nie, is dit nogtans nodig om aan die konsekwensies aandag te skenk wat skrifkritiese opstandingsperspektiewe inhou. In die volgende afdeling van die artikel word enkele van die belangrikste 25.Vir meer inligting omtrent die betroubaarheid van Paulus se getuienis kan die werk
van Paley (1854:263) geraadpleeg word.

26. Henry (1706) verklaar die onderskeie teksgedeeltes soos volg: $\underline{\mathrm{hh}}$ 20:17 Touch me not, for I am not yet ascended. Mary was so transported with the sight of her dear Master that she forgot herself, and that state of glory into which he was now entering, and was ready to express her joy by affectionate embraces of him, which Christ here forbids at this time. Lk 24:42 They gave him a piece of a broiled fish, and of a honey-comb. The honey-comb perhaps, was used as sauce to the broiled and of a honey-comb. The honey-comb, perhaps, was used as sauce to the broiled fish, for Canaan was a land flowing with honey. be raked into, allows Thomas even to thrust his hand into his side, if then at las he would believe. Jh 21:4 Christ appeared to them, not walking upon the water,
because, being risen from the dead, he was not to be with them as he had been; but because, being risen from the dead, he was not to be with them as he had
stand

27.Sien ook Mcdowell (2009:197) se standpunt oor die belangrikheid en die rol van direkte en indirekte getuienis met betrekking tot Jesus se opstanding. konsekwensies van skrifkritiese opstandingsperspektiewe kortliks aan die orde gestel.

\section{Bepaalde konsekwensies van Skrifkritiese opstanding sperspektiewe}

Paulus skryf in 1 Korintiërs 15:14: 'En as Christus nie opgewek is nie, dan is ons prediking vergeefs en vergeefs ook julle geloof'. 'n Belangrike vraag word hier geïmpliseer, naamlik: Indien die liggaamlike opstanding van Christus wegval, wat sal van die Christelike geloof oorbly? Christus se opstanding word direk op een lyn met die opstanding van alle vlees aan die einde van die tyd geplaas. Alhoewel die belofte van deelagtigheid aan die opstanding van alle vlees aan die einde van die eeue een van die kernbetekenisse van die opstanding is, word die fout dikwels gemaak om die ander ryke betekenisse van die opstanding nie raak te sien of te beklemtoon nie.

Van Wyk (2007:2) belig die belangrikheid van die opstandingsleer met die volgende stelling: 'As die opstanding van die liggaam wegval, val die Groot Toekoms weg, dit wil sê die belofte van 'n nuwe hemel en 'n nuwe aarde'. Seker die algemeenste konsekwensie van skrifkritiese opstandingsperspektiewe is die feit dat die gelowige se aanspraak op die hiernamaals daardeur in die gedrang kom. Boice (1986:345) beklemtoon: 'The resurrection of Christ is proof that death is not the end of this life'. Daar bestaan 'n besondere samehang en wisselwerking tussen die leer van die Christologie en die leer van die eskatologie (Potgieter 2001:215-224). Indien die opstanding van Christus wegval, het dit dus ook verreikende negatiewe konsekwensies vir die leer van die eskatologie. Die liggaamlike opstanding van Christus is die gelowige se sleutel om soos Christus die dood oorwin het, ook eendag die dood te oorwin (Van den Brink \& Van der Kooi 2012:398).

Indien Christus nie liggaamlik uit die dood opgestaan het nie, kan gelowiges ook nie die oorwinning oor die dood verkry nie (Hoekema 1979:239). Indien die liggaamlike opstanding van Christus wegval, kom alle aanspraak op die opstanding van alle vlees en die ewige lewe in die gedrang (Nederduitsch Hervormde Kerk van Afrika [NHKA] 1563, Sondag 17). Die uiteinde hiervan is dat die dood sal heers en dat gelowiges geen troos vir 'n verloregaande wêreld sal hê nie (Van Wyk 2007:2). Tereg stel König (2009:173) in ooreenstemming met Handelinge 4:2 dat die opstanding van Christus ook vir Johannes en Petrus die aankondiging van die eindopstanding beteken het.

Daar is ook 'n direkte verband tussen die oorwinning oor die sonde en die liggaamlike opstanding van Christus (Van den Brink \& Van der Kooi 2012:411). Omdat Christus die sonde en die dood finaal oorwin het, kan gelowiges wat in 'n nuwe lewe opgestaan het ook oor die sonde en alle vorms van die dood heers (Rom 6:14). Indien Jesus 
nie die dood oorwin het nie, sou die sonde steeds oor gelowiges geheers het. ${ }^{28}$ Die opstanding van Christus bied vir gelowiges 'n aandeel in 'n nuwe lewe soos Paulus tereg in Galasiërs 2:20 sê: 'en ek leef nie meer nie, maar Christus leef in my'. Die feit dat Christus opgestaan het, beteken dat Hy leef, en indien Hy leef, beteken dit dat Hy ook in ons en deur ons, en ons in Hom kan leef. ${ }^{29}$ Indien Christus nooit opgestaan het nie, sou dit beteken het dat Hy vandag nog dood was en Hy sou ook nie wonderwerkend in ons lewe kon werk nie. Efesiërs 2:4-6 $6^{30}$ stel duidelik dat ons ook saam met Christus opgewek is en dat ons saam met Hom in hemelse plekke sit. Hierdie hemelse plekke spreek daarvan dat gelowiges opgewek en aangestel is om saam met Christus te heers. ${ }^{31}$

1 Korintiërs 15:6 leer dat Jesus by verskeie geleenthede na sy opstanding aan mense verskyn het. Die resultaat van hierdie na-opstandingsverskynings was 'n radikale verandering by diegene wat Hom ontmoet het (Craig 1984:377). Net soos 'n ontmoeting met die opgestane Jesus kort na sy opstanding lewens verander het, is Christus vandag nog by magte om deur die transformerende krag van sy opstanding lewens te verander (Fil 3:10). ${ }^{32}$ Indien Jesus nooit opgestaan het nie het gelowiges nie die vooruitsig om deur 'n ontmoeting met die lewende Jesus verander te word nie. Van den Brink en Van der Kooi (2012) verklaar:

Christus bevrijdt uit de dodelijke machcen die ons leven koeioneren, Hij verzoent de schuld van de zonde, en Hij inspireert en transformeert ons door zijn Geest tot een geheel nieuwe manier van in het leven staan. (bl. 428)

2 Korintiërs 1:9 stel dat God Christus bonatuurlik uit die dood opgewek het. Die feit dat God Christus deur 'n wonderwerk uit die dood opgewek het, beteken dat God ook by magte is om op enige stadium bonatuurlik in ons lewens en omstandighede te werk (Habermas \& Licona 2004:42). Indien Christus nooit die dood oorwin het nie, sou gelowiges ook nie die versekering gehad het dat God bonatuurlik in ons lewens en omstandighede kan werk nie. Die feit dat Jesus opgestaan het, beteken dat gelowiges ook weer en weer kan opstaan, totdat die dag aanbreek wat ons ook soos Christus deur die dood beweeg en die

28. Henry (1706) stel die volgende: 'Sin may struggle in a believer, and may create him a great deal of trouble, but it shall not have dominion; it may vex him, but shall not rule over him. For we are not under the law, but under grace, not in Christ Jesus: we are actuated by other principles than we have been: new in Christ Jesus:
lords, new laws.'

29.Sien ook Boice (1986:344) se literatuur in verband met Christus se opstanding as die seël op God se heiligmaking.

30.Efesiërs 2:4-6 lui: Maar God, wat ryk is in barmhartigheid, het ons deur sy grote liefde waarmee Hy ons liefgehad het, ook toe ons dood was deur die misdade, lewend gemaak saam met Christus - uit genade is julle gered - en saam opgewek en saam laat sit in die hemele in Christus Jesus.

31-Henry (1706) verklaar Efesiërs 2:6 soos volg: They are not only servants to the best of masters in the best work, but they are exalted to reign with him; they sit upon the throne with Christ, as he has sat down with his Father on his throne.

32. Henry (1706) verklaar Filippense 3:10 soos volg: Knowing him here is believing in him: it is an experimental knowledge of the power of his resurrection, and the fellowship of his sufferings, or feeling the transforming efficacy and virtue of them. Observe, the apostle was as ambitious of being sanctified as he was of being
Obstirtue of them. justified. finale oorwinning oor ons omstandighede verkry het (1 Pet 3:21). ${ }^{33}$

In 'n lewe van hartseer, swaarkry en onsekerheid is die vooruitsig op die hiernamaals vir gelowiges 'n onuitputbare bron van hoop (Van Wyk 2007:2). Kolossense 3:3-4 stel die volgende: 'Want julle het gesterwe, en julle lewe is saam met Christus verborge in God. Wanneer Christus, wat ons lewe is, geopenbaar word, dan sal julle ook saam met Hom in heerlikheid geopenbaar word. ${ }^{\prime 34}$

Christelike hoop dryf gelowiges nie slegs nie, maar stel ook 'n geesteskrag beskikbaar wat intellektueel en eties op alle vlakke van gelowige se lewe sigbaar word (Durand 2013:227). Die Christelike hoop word deur die versekering aangevuur dat Christus weer gaan kom en dat gelowiges as nietige mense deel aan daardie koms gaan hê. Skrifkritiese opstandingsperspektiewe ontneem die gelowige van alle vorms van skrifgefundeerde hoop en verwagting.

Die opstanding van Christus is ook die sleutel tot 'n koninkrykslewe hier op aarde. Horton (2011) stel die volgende:

Christ is already a king with his kingdom, but for now this realm is visible chiefly in the public ministry of Word, Sacrament, and disciple, and also in the fellowship of the saints as they share their spiritual and material gifts in the body of Christ. (p. 525)

Durand (2013:121) belig die belangrikheid daarvan dat die koninkryk van God nie eendag in die hiernamaals wink nie, maar dat die koninkryk van God reeds nou al hier op aarde teenwoordig moet wees. Deur die opstanding het Christus gelowiges reeds op aarde toegang tot sy koninkryk gegee. Indien die opstanding van Christus wegval, ontneem dit gelowiges die voorreg om hier op aarde reeds deel aan sy koninkryk te hê.

Skrifkritiese opstandingsperspektiewe verwater die totale pakket van die verlossing wat deur Christus bewerk is (König 2009:13). Die uiteinde hiervan is dat die evangelieboodskap, wat eintlik 'boodskap van goeie nuus' beteken, geen goeie nuus oorgehou het nie. Die Groot Opdrag van die kerk wat op Matteus 28:19-20 berus, behels juis dat gelowiges hierdie 'boodskap van goeie nuus' tot aan die uithoeke van die aarde moet verkondig.

Behalwe vir die opgestane aardse Jesus wat die lyn van kontinuïteit verteenwoordig, is daar ook 'n lyn van diskontinuïteit. ${ }^{35}$ Dit hang ten nouste saam met die

33. Henry (1706) verklaar 1 Petrus $3: 21$ soos volg: The apostle shows that the efficacy of baptism to salvation depends not upon the work done, but upon the resurrection of Christ, which supposes his death, and is the foundation of our faith and hope, to which we are rendered conformable by dying to sin, and rising again to holiness and newness of life.

34. Henry (1706) verklaar Kolossense 3:3 soos volg: We shall then appear with him in glory. It will be his glory to have his redeemed with him; he will come to be glorified in his saints (2 Th. 1:10); and it will be their glory to come with him, and be with him for ever.

35.Van den Brink en Van der Kooi (2012:403) stel die volgende in verband met Christus se diskontinuïteit: 'Bij alle discontinuiiteit in de aard van de lichamelijkheid is er een continuïteit van identiteit. Het is dezelfde persoon die hier was en daar is.' 
eskatologiese Christus en gelowiges se vooruitsig dat hulle liggame ook by die opstanding aan die einde van die tyd verander sal word en aan Christus se verheerlikte liggaam gelyk sal wees (Fil 3:21). ${ }^{36}$ Dit is juis hierdie lyn van diskontinuïteit wat met Christus se verheerlikte liggaam gepaard gaan, wat vir gelowiges 'n onuitputbare bron van hoop bied. Tereg skryf Durand (2013:234) dat die eskatologiese opstanding van die dooies by uitnemendheid die voorwerp van ons hoop verteenwoordig. Filippense 3:20 stel die volgende: 'Want ons burgerskap is in die hemele, van waar ons ook as Verlosser verwag die Here Jesus Christus' ${ }^{37}$ Dit is voorts duidelik dat skrifkritiese opstandingsperspektiewe nie reg laat geskied aan die eskatologiese Christus waarvan ons in die Woord lees nie (Hoek 2003:110).

Die vraag wat gevra kan word, is of die verskraalde beeld wat Skrifkritici van Christus en sy opstanding voorstel genoeg gaan wees om die lewe van 'n sondaar ingrypend te verander. Sonder die opstanding van Christus sou die kerk in haar groot opdrag faal, naamlik om die goeie boodskap van hoop vir 'n verloregaande wêreld te verkondig. Buiten vir bogenoemde konsekwensies is daar vele ander konsekwensies wat nie in hierdie artikel volledig bespreek kan word nie.

Skrifkritiese opstandingsperspektiewe het ook 'n negatiewe impak op die volgende: die verskillende aspekte van die leer van die Christologie, ander leerstukke soos eskatologie en ekklesiologie, roepingsvervulling, sakramente van die kerk, betroubaarheid en gesag van God se Woord, konfessies sowel as die daaglikse geloofslewe van individue (Horton 2011:521-547). ${ }^{38}$

\section{Slotopmerkings}

Die gevolgtrekking word gemaak dat skrifkritiese opstandingsperspektiewe verreikende negatiewe konsekwensies vir die teologie inhou, ook in Suid-Afrika.

Nie net het dit 'n negatiewe impak op die leer van die Christologie nie, maar dit beïnvloed al die ander kernleerstukke van die Christelike geloof. Die konsekwensies van skrifkritiese perspektiewe strek verder as bloot die dogmatiese vlak. Dit het ook 'n impak op die daaglikse geloofslewe van individue en die praktyk van die kerk.

Die gevolgtrekking word gemaak dat skrifkritiese opstandingsperspektiewe onversoenbaar met 'n skrifverantwoorde teologie is.

Die uitkoms van hierdie navorsing toon dat daar die laaste aantal jare 'n drastiese toename in skrifkritiese perspektiewe

36.Van den Brink en Van der Kooi (2012:399) stel tereg: 'Hij is de eersteling van het eschatologische Rijk van God'.

37. Henry (1706) verklaar Filippense 3:20 soos volg: 'There is good reason to have ou conversation in heaven, not only because Christ is now there, but because we hope to be there shortly!

38.Vir meer inligting oor die sake waarna hier verwys word, kan die volgende bronne geraadpleeg word: Blanchard (2009:34); Durand (2013:121, 332); König (1980:136-226); Smith (2011:42-83); en Van der Walt (2006:300) binne die Suid-Afrikaanse teologie was. Hierdie vloedgolf skrifkritiese perspektiewe het weereens bewys dat die tradisionele leerstukke van die Christelike geloof nie in isolasie van mekaar verstaan kan word nie. Daar bestaan dus ' $n$ besondere samehang en wisselwerking tussen die leer van die Christologie en die leer van die eskatologie.

Teoloë wat vir jare lank aan die konfessies van die gereformeerde teologie getrou was, het in die laaste dekade skrifkritiese standpunte begin inneem. Dit is opmerklik dat van die skrifkritiese perspektiewe dikwels deur leiersfigure in die kerklike en openbare lewe gestel word. Hierdie artikel kom egter tot die gevolgtrekking dat skrifkritiese verklarings vir Christus se liggaamlike opstanding nie daarin kon slaag om die tradisionele leer van die opstanding verkeerd te bewys nie. Gegewe hierdie feit bly die enigste logiese gevolgtrekking dat Christus werklik soos die Christelike geloof leer, liggaamlik uit die dood opgestaan het. Die liggaamlike opstanding van Christus is steeds geldig en relevant binne die konteks van 'n postmoderne samelewing.

Dit is duidelik dat daar ' $n$ onoorbrugbare kloof tussen die tradisionele leer van die Christologie en skrifkritiese opstandingsperspektiewe bestaan. In antwoord op die navorsingsvraag van hierdie artikel word gestel dat die gevare van skrifkritiese opstandingsperspektiewe die hart van die evangelie raak. Die eindresultaat hiervan is 'n kragtelose kerk en 'n wêreld sonder hoop of toekomsverwagting.

Uiteindelik bly dit die taak en verantwoordelikheid van skrifverantwoorde teoloë om die omvangryke en kragtige betekenis van die opstanding en die evangelie te bewaar en te verkondig tot op die dag wat Christus weer kom. ${ }^{39}$

\section{Erkenning Mededingende belange}

Die outeurs verklaar dat hulle geen finansiële of persoonlike verbintenis het met enige party wat hulle nadelig of voordelig kon beïnvloed het in die skryf van hierdie artikel nie

\section{Outeursbydrae}

Beide outeurs (Noord-Wes Universiteit) het bygedra tot die skryf en navorsing van hierdie artikel.

\section{Literatuurverwysings}

Berkouwer, G.C., 1967, Dogmatische studiën: De Heilige Schrift, vol. 2, Kok, Kampen. Blanchard, J., 2009, Jesus: Dead or alive, Evangelical Press Books, Darlington. Boice, J.M., 1986, Foundations of the Christian faith, InterVarsity, Illinois.

Bosch, P.B., 2009, 'Die opstanding van Jesus Christus: 'n Histories-sistematiese ondersoek', PhD-proefskrif, Fakulteit Teologie, Universiteit van Pretoria, Pretoria.

Bultmann, R.K., 1984, New Testament and mythology, Fortress, Minneapolis.

Carte Blanche, 2002, 'Onderhoud met Robert Funk', besigtig 29 Maart 2015, by http:// beta.mnet.co.za/carteblanche/Article.aspx? Id=1960

39.Van den Brink en van der Kooi (2012) beskryf die uitdaging van skrifverantwoorde teoloë soos volg: 'De uitdaging waar de dogmatiek voor staat, is nu juist ook zelf binnen de eigen hedendaagse context te vertolken waar het in het geloof ze aankomt - en dat het liefst natuurlijk op een min of meer inzichtelijke en gezaghebbendemanier' (bl. 35). 
Copan, P., 1998, Will the real Jesus please stand up? A debate between William Lane Craig and John Dominic Crossan, Baker Books, Grand Rapids.

Craig, W.L., 1984, Reasonable faith: Christian faith and apologetics, Crossway Books, Illinois.

Craig, W.L., 2009, Jesus' resurrection: Fact or figment? A debate between William Lane Craig \& Gerd Lüdemann, Kindle edn., InterVarsity, Illinois.

Crossan, J.D., 1994, Jesus: A revolutionary biography, Harper Collins, New York.

Crossan, J.D. \& Wright, N.T., 2006, The resurrection of Jesus: John Dominic Crossan and N.T. Wright in Dialogue, Fortress, Minneapolis.

De Wet, C.J.H., 1935, Koers in die krisis, Pro Ecclesia, Stellenbosch.

Driscoll, M. \& Breshears, G., 2010, Doctrine: What Christians should believe, Crossway, Illinois.

Du Rand, J., 2004, 'Jan du Rand' in F. Gaum (red.), 20 Gesprekke oor ... die opstanding van Jesus uit die dood, bl. 44, Ex Animo-boeke, Kaapstad.

Durand, J., 2013, Die einde: Die A-Z van die Bybelse boodskap oor die eindtyd, Christelike Uitgewersmaatskappy, Vereeniging.

Funk, R.W., 1996, Honest to Jesus: Jesus for a new millennium, Harper, San Francisco.

Geisler, N. \& Howe, T., 1992, When critics ask: A popular handbook on bible difficulties, Victor Books, Wheaton.

Habermas, G.R. \& Licona, M.R., 2004, The case for the resurrection of Jesus, Krege Publications, Grand Rapids.

Henry, M., 1706, Matthew Henry's commentary on the whole Bible, besigtig 20 May 2015, by http://www.biblestudytools.com/commentaries/matthew-henrycomplete

Heyns, J.A., 1978, Dogmatiek, NG Boekhandel, Pretoria.

Hoek, J., 2003, 'Towards a revitalisation of Calvinistic eschatology', In die Skriflig/In Luce Verbi 37(1), 95-113. http://dx.doi.org/10.4102/ids.v37i1.460

Hoekema, A.A., 1979, The Bible and the future, Eerdmans, Grand Rapids.

Horton, M., 2011, The Christian faith, Zondervan, Grand Rapids, MI.

Human, D.J., 2004, 'Jona se "opstanding uit die dood": Perspektiewe op die "opstandingsgeloof" vanuit die Ou Testament', Hervormde Teologiese Studies 60(1\&2), 987-1007.

Jordaan, G.J.C., 2003, 'Agtergrond en herkoms van die moderne Skrifkritiek', Voordrag gelewer by die Simposium oor Skrifbeskouing te Witfield, September 2003.

Jordaan, G.J.C., 2005, Nuwe Testament: Gereformeerde hermeneutiek en hermeneutiese strominge, Studiegids Herm875A, NWU, Potchefstroomkampus, Potchefstroom.

König, A., 1980, Jesus die laaste: Gelowige nagedink, deel 2 oor die einde, NG Kerkboekhandel, Pretoria.

König, A., 2004, 'Adrio König', in F. Gaum (red.), 20 Gesprekke oor ... die opstanding van Jesus uit die dood, bl. 18, Ex Animo-boeke, Kaapstad.

König, A., 2009, Die evangelie is op die spel, Lux Verbi, Wellington.

König, A., 2010, Wat kan ek glo? Christelike Uitgewersmaatskappy, Vereeniging.

Krüger, A.J., 2006, 'Skrifkritiek, fundamentalisme en grammaties-historiese eksegese', Die Kerkblad, Okt. 2006, bl. 29-31.

Lane, A.N.S., 2006, A concise history of Christian thought, Baker Publishing, Grand Rapids.

Lennox, J.C., 2011, God and Stephen Hawking, Lion Hudson, London.

Lüdeman, G., 1995, The resurrection of Jesus, history, experience, theology, SCM, London.

Lüdeman, G., 2012, 'A new explanation of the resurrection of Jesus', besigtig 30 May 2015, by www.bibleinterp.com/artcles/lud368017.shtml

Maré, R., 1999, 'Enkele skrifkritiese stellings dogmaties besien', Voordrag gelewer tydens die Simposium Skrifgesag teenoor Skrifkritiek te Pretoria, 29 Oktober 1999.

Mcdowell, J., 2009, Evidence for the resurrection, Regal, Ventura, CA.

Moolman, N., 2011, 'Ooreenkomste tussen Jesus en Boeddha', besigtig 25 Maart 2015 by http://www.spiritualiteit.co.za/artikel-ooreenkomste-jesus-boeddha.php

Moulaison, J.B., 2012, Thinking Christ, Fortress, Minneapolis.

Müller, J., 2006, Opstanding, Lux Verbi, Wellington.
Naudé, S. 2011, 'Die opstanding: 'n Behoefte aan herinterpretasie', besigtig 28 Maart 2015, by http://www.spiritualiteit.co.za/artikel-opstanding-her-interpretasie.php

Nederduitse Gereformeerde Kerk (NGK), 2013, 'Nglynnwood: Moderamen NGK', besigtig 28 Maart 2015, by http://www.nglynnwood.co.za/profiles/blogs/ pastorale-brief-aan-alle-gemeentes-in-die-ng-kerk-moderamen

Nederduitsch Hervormde Kerk van Afrika (NHKA), 1561, 'Die Nederlandse geloofsbelydenis', besigtig 20 Mei 2015, by http://www.nhka.org/index.php/soglo-ons-11/ref-belydenisskrifte/nederlandse-geloofsbelydenis.html

Nederduitsch Hervormde Kerk van Afrika (NHKA), 1563, 'Die Heidelbergse Kategismus', besigtig 20 Mei 2015, by http://www.nhka.org/index.php/so-gloons-11/ref-belydenisskrifte/heidelbergse-kategismus.html

Paley, W., 1854, Paley's evidences of Christianity, Robert \& Carter, New York.

Pienaar, A., 2011, 'Debate - Did Jesus physically rise from the dead?', viewed 20 March 2015, from http://www.spiritualiteit.co.za/artikel-debate-did-jesusphysically-rise.php

Potgieter, P., 2001, 'The consummation of the kingdom of God: Reflections on the final victory of Christ as portrayed in Paul's first epistle to the Corinthians', In die Skriflig/In Luce Verbi 35(2), 215-224, viewed 10 May 2015, from http://dx.doi. org/10.4102/ids.v35i2.556

Saaiman, D., 2005, 'Dogma en Etos: Die eenheid van die bybelse leer en lewe as begronding vir die Christelike etiek in die moderne samelewingskonteks', PhDproefskrif, Departement Etiek, Noordwes-Universiteit, Potchefstroomkampus, Potchefstroom.

Schulze, L.F., 1988, Geloof deur die eeue, Kerkboekhandel, Pretoria.

Smith, S., 2011, 'Die skrifbeskouing van Sakkie Spangenberg: 'n Dogmatiese studie', MA-verhandeling, Skool vir Dogmatiek, Noordwes-Universiteit, Potchefstroomkampus, Potchefstroom.

Spangenberg, I.J.J., 2004a, 'Die geboorteverhaal van die historiese Jesus', besigtig 29 Maart 2015, by http://www.nuwe-hervorming.org.za/wiki/historiese-jesuskersfees

Spangenberg, I.J.J., 2004b, 'Jesus se hellevaart en opstanding', besigtig 12 Mei 2015, by http//www.nuwe-hervorming.org.za/wiki/jesus-se-hellevaart-opstanding

Spangenberg, I.J.J., 2009, Jesus van Nasaret, Griffel Media, Kaapstad.

Spong, J.S., 2001, A new Christianity for a new world, Harper Collins, New York.

Spong, J.S., 2003, 'Bishop Spong on: The Resurrection', viewed 29 March 2015, from http://johnshelbyspong.com/sample-essays/the-resurrection

Strauss, D.F., 1879, The life of Jesus for the people, vol. 1, 2nd edn., William \& Norgate, London.

Strobel, L., 2009, The case for the resurrection, Zondervan, Michigan.

Van Aarde, A., 2001, Fatherless in Galilee, Trinity Press International, Harrisburg.

Van de Beek, A., 2002, Jesus Kyrios: Christianity as the heart of theology, Meinema, Zoetermeer.

Van den Brink, G. \& Van der Kooi, C., 2012, Christelijke dogmatiek, Boekencentrum, Zoetermeer.

Van der Walt, T., 2006, Die Messias het gekom!' $n$ Gids in die Evangelies vir toegewyde bybelstudente, Potchefstroom Teologiese Publikasies, Potchefstroom.

Van Wyk, A., 2007, 'Dié mense skud kern van geloof', besigtig $14 \mathrm{Mei}$, by http://152.111.1.87/argief/berigte/rapport/2007/09/21/RU/2/amie.html

Veldsman, D.P., 1993, 'Die opstanding van Jesus: God se nadergekome en steeds naderkomende protes en liefde', Hervormde Teologiese Studies 49(4), 978-1008. http://dx.doi.org/10.4102/hts.v49i4.2534

Viljoen, F.P., 2002, 'Konsekwensies en beoordeling van kritiese Jesus-navorsing' Die Kerkblad, 10(1231):9, Okt.

Von Harnack, A., 2011, What is Christianity, transl. T.B. Saunders, Martino Fine Books, Eastford

Wedderburn, A.J.M., 1999, Beyond resurrection, SCM, London.

Wheaton, I.I., 1973, 'Die opstandingsberigte', in D.P. Alexander (red.), Handboek by die Bybel, bl. 529, Lion Publishing, Kaapstad.

Wolmarans, H., 2002, 'Die nuwe Hervorming' in P. Muller (red.), Die nuwe Hervorming, bl. 63, Protea Boekhuis, Hatfield.

Wolmarans, H., 2010, 'Gebore uit die maagd Maria', besigtig 29 Maart 2015, by http:// www.nuwe-hervorming.co.za/artikels.php?ipkArticlelD=34 